Discussion Paper No. 14-004

The Indirect Effects of Direct Democracy:

Local Government Size and Non-Budgetary Voter Initiatives

Zareh Asatryan

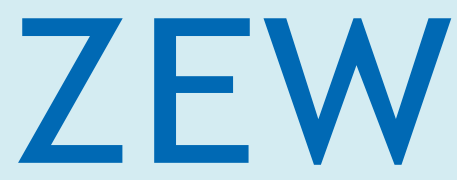

Zentrum für Europäische Wirtschaftsforschung $\mathrm{GmbH}$ Centre for European Economic Research 
Discussion Paper No. 14-004

\title{
The Indirect Effects of Direct Democracy: Local Government Size and Non-Budgetary Voter Initiatives
}

\author{
Zareh Asatryan
}

Download this ZEW Discussion Paper from our ftp server:

http://ftp.zew.de/pub/zew-docs/dp/dp14004.pdf

Die Discussion Papers dienen einer möglichst schnellen Verbreitung von neueren Forschungsarbeiten des ZEW. Die Beiträge liegen in alleiniger Verantwortung der Autoren und stellen nicht notwendigerweise die Meinung des ZEW dar.

Discussion Papers are intended to make results of ZEW research promptly available to other economists in order to encourage discussion and suggestions for revisions. The authors are solely responsible for the contents which do not necessarily represent the opinion of the ZEW. 


\title{
The Indirect Effects of Direct Democracy:
}

\section{Local Government Size and Non-Budgetary Voter Initiatives}

\author{
Zareh Asatryan* \\ (ZEW Mannheim and University of Freiburg)
}

January, 2014

\begin{abstract}
Recently a wide and empirically-backed consensus has emerged arguing that direct democratic control over government's spending decisions through initiatives and referenda constrains government size. But what happens if budgetary matters are excluded from the voters' right of the initiative? I study this question by extending the analysis to German direct democracy reforms of the mid-1990s, which granted voters wide opportunities to initiate referenda on local issues, but neither the right, nor the responsibility of voting on the implied costs of these initiatives. By exploiting a novel dataset containing detailed information on close to 2,300 voter initiatives in the population of around 13,000 German municipalities from 2002 to 2009, I show that in this sample - and in contrast to the Swiss and US evidence - direct democracy causes an expansion of local government size by up to $8 \%$ in annual per capita expenditure and revenue per observed initiative (on economic projects). The main empirical challenge is the endogeneity of voters' unobserved preferences which simultaneously determine both their propensity towards exploiting their direct democracy rights and their preferences for local public policies. To address this issue I use state- and municipality-varying legislative thresholds on the minimum number of signatures required to initiate referenda and the time to collect these signatures as strong and exogenous instruments for observed initiatives.
\end{abstract}

Keywords: Direct democracy, local public finances, Germany

JEL codes: D72, D78, H70

*Address of correspondence: Zareh Asatryan, ZEW, L7 1, 68161 Mannheim, Germany; Tel.: $(+49) 6211235392$; Email: asatryan@zew.de

The author gratefully acknowledges Thushyanthan Baskaran, Nadja Braun Binder, Benny Geys, Friedrich Heinemann, François Laisney, Johannes Voget and seminar participants at ZEW Mannheim for valuable comments, as well as Amadeo Dal Borgo for excellent research assistance. 


\section{Introduction}

Whether and how direct democracy affects government size is a non-trivial question. The practice of delegating a part of the decision-making power from elected representatives directly to voters through mid-election initiatives and referenda ${ }^{1}$ on single-issued topics implies serious changes to the political process that determines the equilibrium economic and fiscal policies. In an ideal median voter world competition between politicians (the agent) should drive the bundle of government policies to the point preferred by the median voter (the principal). Public choice scholars, however, argue that the government has a systematic over-spending bias because of the influence of bureaucrats' detrimental incentives, lobbying by special interest groups, log-rolling in the legislature or all sorts of other principal-agent problems (Brennan and Buchanan, 1980).

Direct citizen approval of spending decisions via referenda has been for long viewed as one mechanism of the fiscal constitution that constrains the government's inherent overspending bias (Romer and Rosenthal, 1979), for example, by bringing actual policies closer in line with the fiscally more conservative preferences of the median voter (Peltzman, 1992). Even more so for the right of the initiative, which, by granting citizens wider opportunities to set the political agenda, further shifts the power to voters themselves, thus alleviating the principal-agent problems. This logic is then extended to a broader umbrella term - direct democracy - with an empirically-backed consensus that direct democracy negatively affects government size (Kirchgässner, 2000).

This paper argues that this relatively broad consensus does not capture the complete story. First, the evidence is based on the experience of a few countries - the US, Switzerland and more recently also on Sweden $2^{2}-$ and thus critically depends on their distinct

\footnotetext{
${ }^{1}$ The word referendum derives from the Latin verb "referre" meaning to refer, I therefore use its Latin plural form referenda rather than the English plural referendums. Both forms, however, are grammatically not incorrect and can be used according to the user's preference.

${ }^{2}$ Among others Zax (1989); Farnham (1990); Matsusaka (1995); Camobreco (1998); Matsusaka (2000); Bails and Tieslau (2000); Besley and Case (2003); Blomberg et al. (2004); Marschall and Ruhil (2005); Primo (2010); Salvino et al. (2012) for the United States; Pommerehne (1978); Feld and Kirchgässner (2001); Feld and Matsusaka (2003); Funk and Gathmann (2011) for Switzerland; and Hinnerich and Pettersson-Lidbom (2012) for Sweden.
} 
systems of fiscal governance. This lack-of-generality argument is especially worrisome, because often direct democratic institutions are more applied at state- and local- levels where the cross-country heterogeneity in fiscal institutions becomes more apparent than at the national-level. More importantly, however, I argue that the institutions of direct democracy are decisively different 3 As much as it is odd to compare representative democracies without looking at the relevant institutional differences, it is likewise problematic to use the broad term of direct democracy as a simple universal institution.

Against this background, this paper pioneers to extend the analysis to Germany ${ }^{4}-$ a compelling case of comparison - where in the mid-1990s its states, the Länder, have independently gone through a series of reforms introducing non-identical institutions of direct democracy at the local level. As a result, now all German municipalities allow for the right of the voter initiative. The critical difference of German direct democratic institutions to that of Swiss or US ones is that the constitutions of all German states share the common property of the so called fiscal-taboo, i.e. initiatives directly related to municipal budgets are prohibited by all state constitutions. This is critical to the developed mechanism on how direct democracy affects fiscal outcomes, because, as discussed above, it is precisely the citizens' right to veto the government's spending decisions that serves as the mechanism to constrain its over-spending bias. Now, what happens if voters are granted the right to set the agenda and directly vote on projects of their own choice - including ones relevant for the economy and, thus, indirectly to the fiscal system as

\footnotetext{
${ }^{3}$ Recent attempts to distinguish between cross-country differences in direct democratic institutions are made by Blume et al. (2009) and Blume and Voigt (2012). Among other things, the latter study finds that the right of referenda at the national level is negatively correlated to government spending, while initiatives have an opposite relation. Freitag and Vatter (2006) make a distinction between fiscal referenda and initiatives in the Swiss context, and find that only the former matter for taxation-related outcomes.

${ }^{4}$ There are two recent exceptions. Firstly, Blume et al. (2011) compares local government expenditures in the state of Baden-Württemberg to that of the neighboring state of Bayern exploiting the fact that direct democracy was introduced at different time points in the two states. The study, however, remains descriptive in nature due to the small number of observations, as the local level fiscal data is aggregated to state level. Also, the heterogeneity of direct democratic institutions of the two states - a fact I show later in the paper - makes them hard to compare. Secondly, Asatryan et al. (2013) and Asatryan et al. (2014) address many of the empirical concerns by presenting quasi-experimental evidence on, respectively, spending- and taxation- related effects of initiatives. However the paper concentrates only on one German state, Bayern. Both studies find that in their given samples direct democracy expands local government size.
} 
well - but neither having the right, nor the responsibility of voting on the implied costs of these initiatives?

Surprisingly, this property has discouraged economists from doing any research on understanding the budgetary effects of German direct democratic institutions, possibly assuming that the fiscal-taboo by definition implies irrelevance of the initiatives for the budgets. On the contrary, this paper exploits a novel dataset $5^{5}$ containing detailed information on close to 2300 voter initiatives that took place in the universe of around 13,000 German municipalities from 2002 to 2009 to study their effect on local public finances. To address the well-recognized endogeneity between direct democratic activity and local public policies (e.g. Marschall and Ruhil (2005); Funk and Gathmann (2011); Asatryan et al. (2013)), I use state- and municipality-varying legislative thresholds on the minimum number of signatures required to initiate referenda and the time to collect these signatures (as well as other differences in state legislations) as exogenous predictors of observed initiatives to build an instrumental variable identification.

Unlike the seeming irrelevance of these initiatives for fiscal performance, the results indicate that in my sample - and in contrast to the Swiss and US evidence - direct democracy causes an expansion of local government size amounting to an average increase of up to $8 \%$ in annual per capita expenditure and revenue per initiative on economic issues. I also show, that this expansion of government size is (at least partly) financed by increased local tax rates (on property and local businesses) and not through budget deficits.

The remainder of this paper is structured as follows: in Section 2 I discuss the German direct democracy reforms, and since these are being analyzed for the first time, I go in some detail to present descriptive evidence on the cross-state differences in these

\footnotetext{
${ }^{5}$ By stressing this innovation, I aim at inviting researchers' attention to the many interesting features of this new database. The large number of observations combined with quite substantial variations both in direct democratic institutions and in the intensity, types, topics, timing (and other details) of observed initiatives and referenda should make the data useful not only in different branches of economics (public economics, political economics, urban and regional economics etc), but also relevant for scientists working in other fields such as political science, law, governance, public administration, electoral studies etc.
} 
institutions. In subsequent Section 3 I describe the data and develop the identification strategy. Section 4 presents the results, followed by conclusions in Section 5 .

\section{German Institutions of Direct Democracy}

At least for the post World War II period, Germany has not been too famous for its direct democratic institutions. And rightfully so: Although the first German democratic constitution of the Weimar Republic (1918-1919) included various elements of direct democracy (Schiller, 2011), the multiple uses of plebiscites in 1934, 1936 and 1938 by the Nazi dictatorship to legitimize their draconian power discredited the concept of direct democracy for the decades to come (Schiller, 2011). As a result the new post-war constitution of the Federal Republic of Germany, the "Grundgesetz", was almost purely representativ£, and to date there has not been any practice of direct democracy on the national level Eder et al., 2009). On the sub-national levels, the constitutions in seven states (all Western) allowed for some - although very restrictive - elements of direct democracy (Setala and Schiller, 2012), while at the municipal level laws of state-imposed direct democracy were virtually non-existent.7队

The years 1989-1990 and the peaceful collapse of Communism in Eastern Germany mark a turning point. Since German reunification most Länder adopted or liberalized their direct democracy laws on the state level, and all Länder have independently gone through a series of reforms introducing non-identical institutions of direct democracy at the local level. In today's practice it seems direct democracy is becoming part of Germany's political scene - a fact, I argue, largely neglected in the economics profession.

The former East German states, motivated to rebuild their institutions of participatory democracy, were the first to grant their citizens the right of local-level initiatives

\footnotetext{
${ }^{6}$ Except for a mandatory referendum for territorial changes.

${ }^{7}$ The only exception is the state of Baden-Württemberg, where the right to initiate referenda was introduced to municipal law in 1956.

${ }^{8}$ To avoid confusion, throughout the study I will use the German names of the states rather than their English translations.
} 
and referenda $\Omega^{9}$ The Western states followed 10 however, with quite a different motivation. Here the innovation was largely determined by the need to reform the local public administration towards strengthening its efficiency in the new competitive environment, and was undertaken parallel to other administrative reforms (Wollmann, 2000).

A remarkable case was the direct democratic reform in Bayern. Rather than a change imposed by politicians, here the reform came bottom-up through the right of the citizen initiative at the state level. Despite significant barriers, a popular mobilization in 1995 collected nearly 1.2 million signatures comfortably passing the requirements to initiate a state-wide referendum ${ }^{11}$ demanding direct democracy at the local level. The initiative was implemented as a referendum later that year collecting 57.8\% "Yes" votes Verhulst and Nijeboer, 2008). Due to its strong roots, the Bavarian direct democratic institutions turned out to be one of the most comprehensive ones among German states both in terms of their legislative openness and their exhaustive usage in practice. Citizens of the state of Hamburg in 1998 and those of Thüringen in 2009 went through a similar path by exploiting their right of the initiative at the state level to introduce and reform direct democracy at the local level. Non-coincidentally, the latter two states ended up with quite strong direct democratic institutions too.

These cross-state historical differences in their paths to direct democracy imply interesting variations in their direct democratic institutions. I summarize the most relevant ones in Table 1. The most usual instrument of direct democracy, present in all states, is the right of the citizen-initiative ("Bürgerbegehren") that voters can launch on an issue within the competencies of the municipality. If the given amount of signatures (the thresholds are presented in columns 2-3 of Table 1) are collected within the maximum allowed time (column 6), the initiative is implemented as a referendum ("Bürgerentscheid") which is then additionally subject to certain quorum requirements (columns 4-5). Most,

\footnotetext{
${ }^{9}$ Including Brandenburg, Mecklenburg-Vorpommern, Sachsen, Sachsen-Anhalt and Thüringen in 1990-1993, and Berlin later in 2005.

${ }^{10}$ Including Bayern, Bremen, Hamburg, Hessen, Niedersachsen, Nordrhein-Westfalen, Rheinland-Pfalz and Saarland in 1993-1998, Schleswig-Holstein earlier in 1990, and Baden-Württemberg, as noted, in 1956.

${ }^{11}$ Around 900,000 signatures (10\% threshold) were to be collected in two weeks time.
} 
but not all, states also allow for the council-initiative ("Ratsreferendum"), which is a referendum called by city councils (on average about a tenth of all initiatives). Regarding the topics, all states - as discussed earlier and one of the focal points of this paper exclude the possibility of initiatives directly concerning the municipal budgets (i.e. the fiscal-taboo), and have different lists of other prohibited topics (the so called off-limits issues). In addition some states restrict the topics of initiatives by a catalogue of allowed issues (positive-topics: column 8), and all states with the exclusion of Bayern and the city-state of Bremen require to submit a cost recovery proposal with the initiative. These differences suggest a great deal of variation in the actual use of observed initiatives and referenda (columns 10-11).

Most notably in Bayern, the liberal direct democratic institution: ${ }^{12}$ adopted in 1995 imply the highest number of observed initiatives (around 900 for the period between 2002 to 2009) and the highest rate of success of $47 \%$ (Figure 1). In contrast, its Western neighbor Baden-Württemberg ${ }^{13}$ of around the same size, where direct democracy has been in place decades earlier (since 1956), but with much tighter regulations, hosted only 203 initiatives in the same period.

Regarding the topics of initiatives, it seems people are most concerned when it comes to securing general public services. As shown by Figure 2 almost every second initiative is about infrastructural projects such as transportation, basic supply of water, energy and other utilities, and, importantly, also including social infrastructure such as health, education or other facilities under municipal discretion. The second most frequently observed category are the economic issues with over a quarter of all initiatives. Given the fiscal-taboo, these are again initiatives to secure the desired amount of local public goods - often with no necessary consideration of their implied costs for the local budgets - and include topics such as contra-privatization proposals, blocking the construction of various economic projects such as energy plants, mobile-phone towers, shopping centers etc. The

\footnotetext{
${ }^{12}$ Low signature and quorum thresholds, unlimited time for signature collection, absence of a cost recovery proposal requirement, relatively broad areas where initiatives are allowed etc.

${ }^{13}$ With higher quorum thresholds, a few weeks of time for signature collection, cost recovery proposal requirement, wide restrictions on topics of initiatives etc.
} 
proposed direct costs of initiatives are often not too high - on average ranging from 14,000 Euros in Sachsen-Anhalt to over 155,000 Euros in Nordrhein-Westfalen (column 9 of Table 1) - and they are certainly not higher for economic initiatives (Figure 2). The indirect losses, however, such as through unrealized private sector investments, may imply certain costs to the local budgets. On the other hand, as discussed in the introduction the right of the initiative gives the voters the tool to act as a watchdog against bureaucrats' possible failures in designing and implementing fiscal policies. This is the main dilemma I will face throughout the paper.

\section{Data and Identification}

The sample consists of an unbalanced panel of the population of 12,000 to 13,000 German municipalities across 12 of its 16 states for the period between 2002 and 2009. The city-states of Berlin, Bremen and Hamburg, as well as the small state of Saarland are excluded from the analysis 14 For the resulting sample I collect town-level information on the observed initiatives, and also data on municipal fiscal and other characteristics. Table 2 provides complete summary statistics of the variables used in the analysis.

First regarding the data on direct democracy, I collect state-level information on direct democratic institutions from the respective state constitutions. The previous section has a detailed discussion on these institutions, which are summarized in Table 1. This institutional data is then complemented by a novel dataset on the actual usage of direct democratic tools, i.e. data on the observed initiatives (including information on the date these were implemented, their type, the proposed cost that these initiatives would imply, their topic and the result) for the population of German towns.

Concerning municipal characteristics, my main fiscal variables of interest are: total annual per capita expenditure and revenue in real terms; local budget deficits as share of

\footnotetext{
${ }^{14}$ I exclude these from the sample for two reasons: first because very few initiatives have been observed here; and secondly, regarding the city-states, initiatives are implemented either on city- (same as state) or city-district- levels, both being incomparable to municipalities.
} 
budget revenues; and the two sorts of taxes over which municipalities have full discretion to decide the rate and the base, thus their main source of autonomous income other than borrowing. These taxes include local multiplier on the business tax and on the property tax (with two different A and B rates respectively applied on agricultural land and all other property). A standard set of control variables are also employed including: level of total population, share of working age population and share of unemployed as demographic statistics, and share of the sum of left- and right- leaning delegates at local councils to control for ideological differences.

I am interested to study the causal effect of direct democracy on local fiscal outcomes. The regression on fiscal outcomes takes the following form:

$$
\text { FiscalVar }_{i t}=\alpha_{1}+\delta \cdot \text { DirectDemocracy }{ }_{i t}+\beta_{1} \cdot \text { Controls }_{i t}+\mu_{1 c}+\eta_{1 t}+\epsilon_{1 i t},
$$

where the dependent variable FiscalV ar is the fiscal variable of interest as specified above (i.e. expenditure, revenue, taxes, or deficit). On the right hand side, Controls is a set of standard demographic and political controls again listed above, and DirectDemocracy is a binary variable indicating whether an initiative has taken place in municipality $i$ in year $t . \mu$ and $\eta$ are county and year dummies, ${ }^{15}$ and $\epsilon$ is an unobserved error term.

Now, the main challenge is to solve the obvious endogeneity between direct democracy activity and local fiscal policies. Such endogeneity arises, for example, because of voters' preferences that simultaneously determine both their propensity towards exploiting their rights given by direct democracy laws and their preferences for local fiscal policies. Obviously, I can not control for such bias in Equation 1, since voters' preferences, as in the example, are unobserved and, thus, are included in the error term violating its

\footnotetext{
${ }^{15}$ Counties are a unit of organization one step higher than the towns and are equivalent to the European NUTS3 classification. They are defined either on the level of individual cities ("Kreisfreie Stadt") or, in rural areas, on the level of counties including several towns ("Landkreis"). Since the smaller towns united in counties are likely to have the common unobservables, I control for unobserved heterogeneity on the level of counties (around 400) rather than for each municipality (over 12,000).
} 
independence assumption. As shown by Asatryan et al. (2013) causality might well be problematic as well, since voters do not have to wait until the next elections anymore, but can directly react to government policies (e. g. changes in the level of spending or taxation) with opting for more or less initiatives.

I solve this endogeneity problem by the means of a two stage instrumental variable identification strategy. The first-stage specification, where the latent DirectDemocracy* variable is regressed on a set of exogenous instruments and all of the previous regressors (including the fixed effects), takes the following form:

$$
\text { DirectDemocracy }_{i t}^{*}=\alpha_{2}+\gamma \cdot \text { Institutions }_{i t}+\beta_{2} \cdot \text { Controls }_{i t}+\mu_{2 c}+\eta_{2 t}+\epsilon_{2 i t} \text {, }
$$

$$
\text { DirectDemocracy }_{i t}= \begin{cases}1, & \text { if DirectDemocracy } \\ 0, & \text { otherwise }\end{cases}
$$

where the new Institutions variable is a set of exogenous variables capturing stateimposed direct democratic institutions, including: a dummy on the presence of a list of positive-topics in state constitutions; the maximum allowed time (in weeks) to collect signatures for initiating citizen-initiatives; and also the minimum requirement for the number of signatures to be collected and, likewise, the quorum thresholds on the number of casted eligible votes for the referenda to be approved. All these institutional characteristics should be relevant for the likelihood of an initiative (non-zero covariance between DirectDemocracy and Institutions), therefore, I will use these institutions as instruments for initiatives. For my identification to be valid, it is essential that these variables are exogenous to the frequency of observed initiatives. This is clearly the case, because of three reasons: first, these laws were adopted well before the period of analysis and mainly in the mid-1990s, but in some cases as early as 1956 (Table 1); second and more importantly, the laws are adopted at the state-level - and not by the local governments - either by the state parliaments or through popular referenda at the state-level such as 
in Bayern in 1995; third, these laws also contain some degree of randomness in certain neighborhoods - the signature and quorum thresholds, for example, not only vary by state but also by towns within states depending on (quasi-randomly) selected population thresholds at round numbers (Asatryan et al., 2013).

Thus I have a set of instruments that satisfy the exogeneity assumption, but also importantly have a good deal of variation as they vary both by- and within- states, and also over-time (because of (state-level) changes in institutions and (town-level) population growth or decline). For the two-stage least squares (2SLS) estimator to be consistent, as usual, I further assume that there is no perfect linear relationship between the instruments, and that the error term of Equation 1 has a zero mean and is uncorrelated with any of the instruments. For asymptotic efficiency, I report standard errors that are robust to heteroskedasticity of unknown form.

\section{Results}

The current section starts by presenting the results from the first-stage regression on the determinants of initiatives and referenda. This is essential in identifying the instruments, which I will then use to estimate the causal effect of direct democracy on local government aggregate size and on the budget items in detail. The discussion of results ends with several robustness tests.

\subsection{First-Stage Results: Determinants of Initiatives}

Table 3 presents results from estimating Equation 2 using an OLS approach in columns 1-8 (since both stages of the 2SLS are OLS) and a probit regression in columns 9-10 (to account for the non-linearity coming from the binary nature of the dependent variable). In the first three specifications the dependent variable measuring direct democracy activity is initiative (a total amount of 2288 over the whole sample): first, in the baseline case, it is regressed on two of the instruments without controls (note that column 1 is estimated 
on a much larger set of observations, due to missing values in the control and fiscal variables), then adding the controls, and in column 3 with the whole set of institutional variables. For robustness, in the subsequent columns I also introduce alternative variables of direct democracy, namely: economic-initiative and infrastructure-initiative - initiatives on the given topics of interest (about $27 \%$ and $45 \%$ of initiatives respectively); citizeninitiative - an initiative initiated by the citizens (about $88 \%$ of initiatives); councilinitiative - an initiative initiated through the local council and not by citizens (about 11\% of initiatives) $\sqrt[16]{16}$ and referendum - a citizen- or council- initiative that has successfully gone through the legal procedure and was put to vote - (about $35 \%$ of initiatives).

Importantly for my identification, the results on the hypothesized instruments are strong and robust, and have the expected signs: higher signature requirements are significantly correlated with fewer initiatives and referenda; longer signature collection periods are associated with more initiatives and referenda: $:{ }^{17}$ and the presence of a positive list of allowed topics in state laws are related to fewer initiatives. The latter behaves as expected, however it has a small variance due to within-state homogeneity. The coefficient on the quorum requirement is negative as expected, but is not significant again possibly due to small variance. The signature requirement and the signature collection time, on the other hand, seem to be quite strong and robust determinants of observed initiatives and referenda. Thus, I will employ these two as the main instruments for the second-stage regressions.

Other than the institutional determinants of direct democratic activity, it is also interesting to observe that the size of the town, the share of unemployed and the share of kids and pensioners are all positively correlated with the number of initiatives. Local government expenditures is also among the positive and robust determinants of initiatives,

\footnotetext{
${ }^{16}$ The results on the council-initiative can be viewed as a placebo test, since the city councils are not subject to these legal constraints and have other procedures for initiating referenda. As expected, column 7 of Table 3 shows null results for both of the instruments.

${ }^{17}$ Note that I take the inverse of the collection time variable, since some states in the sample (e.g. Bayern) do not have such restrictions, so a zero means unlimited time.
} 
suggesting that addressing the issues of endogeneity and reverse causality are of crucial importance.

\subsection{Main Results: Direct Democracy and Government Size}

The reduced form results of the 2SLS estimation of the effects of direct democracy on local government size as specified in Equations 1 and 2 are presented in Tables 4 and 5. Initiatives have a significantly positive impact on both government expenditure and revenue. The size of the effect amounts to an average of around $1.5 \%$ increase in both per capita expenditure and revenue per observed initiative. ${ }^{18}$ Since it may take some time until the fiscal system realizes the effects of initiatives, in columns 5-8 and 9-12 of both tables I also specify the direct democracy dummies respectively with first and second lags. The results are robust to specification. Likewise, for the referendum dummy - which indicates the initiatives that were put to vote - the coefficient is larger as expected since the scale of the effect is net of the failed initiatives.

The results become stronger in size when I differentiate the initiatives according to their topics: initiatives broadly defined to be economic projects (that make around $27 \%$ of all initiatives) on average have a twice larger impact on government size than the initiatives categorized to be on infrastructure including social and educational institutions, but also projects on transportation and on all other local infrastructure (that make around $45 \%$ of all initiatives). At first sight, this may seem somewhat surprising as the infrastructural projects are on average more costly (around 65,000 Euros per initiative according to the cost recovery proposal) than the economic projects (less than 40,000 Euros). However, as I argue throughout the paper, it is possible that the direct costs of the initiatives (in any case quite low for both categories as an average town spends around 15 million Euros annually) are outweighed by indirect losses due to, for example, unrealized private sector investments - a discussion to which I come back in the conclusions.

\footnotetext{
${ }^{18}$ Although some state- and size- dependent differences exist, typically German municipalities are responsible for the provision of important public goods to citizens such as kindergartens, elementary schools, utility and infrastructure facilities, local streets, athletic areas, basic health care etc.
} 


\subsection{To Borrow or to Tax?}

Next I extend the discussion and ask how is this quite substantial increase in government size (of up to $6-8 \%$ of per capita expenditure and revenue on average per economic initiative) financed? As described above German municipalities have quite wide expenditure duties, however these are only partly financed locally, the rest being covered through intensive federal and state equalization schemes (by both block and special purpose grants). The two important sources of local autonomous revenue are: first, the borrowing option subject to certain fiscal constrains; and, secondly, the tax on property and the trade tax on local businesses ${ }^{19}$ The revenue from own taxes, according to Table 7 , on average make up around $18 \%$ of local budget revenue, a significant share being raised through the local business tax and to lesser extent through the property tax on real estate (type B property) 20

In Table 6 I estimate similar regressions as before, ${ }^{21}$ but as the dependent variable taking the local tax rates on property and businesses (columns 1-4 and 5-8) and the local budget surplus or deficit (columns 9-12) ${ }^{22}$ As before economic initiatives seem to matter the most, and the evidence points to the direction that increased government size is financed through an increase of local tax rates and not through deficit-spending. Quite the contrary, initiatives even increase the budget surplus.

The latter results on budget balances are consistent with the evidence both from Switzerland and the US. Feld and Kirchgässner (2001) find that budget deficits and public debt are lower in municipalities which have the right of referenda, arguing that the people themselves appear to care more about fiscal discipline than their elected representatives. Similarly, Kiewiet and Szakaly (1996) show for a panel of the US States

\footnotetext{
${ }^{19}$ The tax bases are uniformly defined nationwide but municipalities have complete independence in deciding the tax rate by setting a tax multiplier.

${ }^{20}$ Property tax type-A is applied on agricultural land, which raises less than $1 \%$ of total revenue property, thus, I neglect it in the analysis.

${ }^{21}$ To preserve space, from now on I will only report the first-lagged results.

${ }^{22}$ And not data on debt since, although preferred, stock data on local government borrowing for this large sample is not available.
} 
that the referendum requirement poses a strong restriction on the issuance of guaranteed debt.

The results on tax rates are fairly important too, as the two considered property and business taxes yield significant revenues for the local budget while being one of the few policy tools that are completely under the local authorities' discretion. These results are also interesting in the sense that there is not much evidence on tax related effects of direct democracy, even from countries where direct democracy is a much more evolved and functioning institution than in Germany. One exception is Feld and Kirchgässner (1999). Although the paper finds that Swiss cities with budgetary referenda spend less (a rather general result for direct democracy), they at the same time have higher tax rates and also a higher share of revenue from taxes and user charges, as opposed to transfers and subsidies.

In my context this evidence may imply that voters are demanding more public goods by exploiting their right of the initiative, but, importantly, are not reluctant to internalize (at least part of) the costs of providing these additional units of local public goods.

\subsection{Structure of the Budget}

In this sub-section I re-estimate the 2SLS regressions on the structure of local expenditures and revenues. The reduced-form estimates are summarized in Table 8 . These additional regressions strongly support my previous findings, as the positive and significant results are robust to most items of the local budget.

One interesting exception emerges. Expenditure on personnel, which take around 16\% - a fairly significant share - of municipal spending, is negatively affected by initiatives (column 4). Consistent with this evidence, Matsusaka (2009) shows that the right of the initiative is associated both with employment and wage cuts of public sector employees. Based on theory and data from US cities, Matsusaka (2009) then argues that the initiative process enables individuals and groups outside the government to check the behavior of elected officials, who often tend to pad the public payroll with patronage workers. 
Similarly, Frey et al. (2001), based on labor force survey data from Switzerland, find that public employees receive lower financial compensation under more direct democratic institutions.

This exception may serve as another step in understanding the main question studies in this paper: why is the fiscal-taboo so important, and why does it reverse the fiscal effects of direct democracy? The initiatives that could potentially affect the local expenditure on personnel are not considered as directly budget-related - but rather take the form of initiatives on, for example, government reform (Figure 2; around 10\% of all initiatives and almost always with zero proposed costs) - and, thus, are not restricted by the fiscaltaboo even though they obviously have non-zero implications for the budget. Since the mechanism described by Matsusaka (2009) on how initiatives constrain public spending employment and wages is similar to the more general channel between direct democracy and government size, it become logical to expect that it is precisely the fiscal-taboo that drives the opposite results between the different items (personnel expenditure vs. others) of the budget.

The second exception is the negative coefficient of the expenditure on property investment (column 6), and relatedly the loss in revenue from capital (column 10). Although, international evidence to cross-validate the results is non-existent, there is an interesting parallel between the two exceptions. Both personnel expenditure and property investment are expenditures targeted at certain groups of voters, i.e. public employees and future property owners, respectively. If these results are true, they might be evidence of a phenomenon that is more general than the one described by Matsusaka (2009). Under direct democracy, voters have increased powers to limit the amount of government spending going to targeted minorities (often protected by interest groups, for example) to the benefit of the wider electorate. 


\subsection{Robustness Tests}

As the title suggests, this final sub-section aims at validating the accuracy of the results with several robustness tests.

Tables 9 and 10 present the estimations first on expenditure and revenue, and then on taxes and budget balances. The first column is an OLS specification of Equation 1 where the endogenous direct democracy variable is simply included in the right hand side. Then I specify three variants of the previous 2SLS with different set of instruments. In all cases the different 2SLS estimations yield identical results suggesting that the results are not sensitive to the choice of instruments. With the exception of the regression on budget deficits, 2SLS estimates also yield results that are consistent to that of OLS estimations.

Finally, in the last columns in the panels of each of the dependent variables I specify a control function $(\mathrm{CF})$ method. Here, the idea is to adequately treat the binary nature of the endogenous variable, as opposed to the 2SLS regressions which estimate linear functions in both of the stages. This standard 2SLS approach, that ignores the discreteness of the endogenous variable, as suggested by Angrist and Pischke (2008) is not incorrect and is certainly widely applied ${ }^{23}$ The control function approach, however, could lead to more efficient estimates as suggested by Imbens and Wooldridge (2007). Intuitively, the idea behind the two-step control function approach is to express the second-stage error, $\epsilon_{2}$, with the first-stage error term, $\epsilon_{1}$. Because the unexplained part of $\epsilon_{2}$ is correlated with the endogenous variable, DirectDemocracy, I want to directly "control" for this bias by including $\epsilon_{1}$ as an explanatory variable in the second-stage equation. Although this error term is unknown, one can substitute for its fitted values coming from first-stage probit estimates.

In cases of expenditure, revenue and budget balances the control function approach does not yield significant results for the direct democracy variable. The results are consistent with my previous results only in the two tax regressions. In any case, Imbens

\begin{tabular}{|l|}
\hline \hline${ }^{23}$ Some well known application are, for example, $\mid$ Angrist $\mid(1990)$ or $\mid$ Imbens and Klaauw|(1995). $\mid$ Angrist \\
\hline and Krueger|(2001) has a brief summary of other similar works and $\mid$ Angrist|(2001) extends the discussion \\
\hline to cases where the (second-stage) dependent variable is also limited. \\
\hline
\end{tabular}


and Wooldridge (2007) point to efficiency gains of the CF approach as opposed to the standard 2SLS techniques, but also warn against its lack of robustness and its sensitivity to specification. In my sample, the potential efficiency gains do not materialize.

\section{Conclusions}

In this paper I extend the literature on the fiscal effects of direct democracy to all German municipalities. I exploit the fact that in mid-1990s most German States have independently gone through a series of reforms introducing non-identical institutions of direct democracy at the local level. These between-state variations in direct democratic institutions, as well the resulting observable initiatives and referenda, are used to study the causal effect of direct democracy on fiscal outcomes.

A number of interesting results emerge. First, the analysis shows that direct democracy causes an expansion of local government size by up to $8 \%(3 \%)$ in annual per capita expenditure and revenue per observed initiative on economic (infrastructural) projects. This result is in contrast to most evidence from Switzerland or the US. However, a crosscountry comparison of results is not straightforward since the institutional context (both in direct democratic and fiscal institutions) is quite different from country to country. As discussed by Asatryan et al. (2013) - that finds similar expansionary impact of direct democracy based on quasi-experimental evidence from the German State of Bayern - a plausible explanation is the German cooperative form of federalism that induces strong common-pool disincentives on part of local voters which are then realized through initiatives and referenda.

Another interpretation - albeit not a direct empirical test - that I develop throughout the paper, is the property of the so called fiscal-taboo common to all state legislations on direct democracy in Germany. While these reforms granted German voters the right to set the agenda and directly vote on projects of their own choice, they neither gave the right to veto governments' fiscal decisions, nor the responsibility to necessarily vote on 
the implied costs of these initiatives. Theory and evidence, however, suggests that it is precisely the citizens' right to veto government's spending decisions - and not any kind of direct democracy such as the right of the initiative - that serves as the mechanism to constrain its over-spending bias. It should then not be surprising to observe a reversed effect of direct democracy when the primary direct mechanism is blocked by law, since this exclusion restriction significantly weakens the voters' powers to act as a watchdog (to block inefficient government spending decisions). On a more practical level, politicians' reluctance of insisting on the fiscal taboo because of the voters' assumed intrinsically selfish, non-mature or even irresponsible behavior regarding their voting pattern on budgetary issues - but not on other issues - might well be the reason of these divergent cross-country results.

Secondly, I find that this expansion of government size is (at least partly) financed by increased local taxes and not through budget deficits. In my context this evidence may imply that voters are demanding more public goods by exploiting their right of the initiative, but, importantly, are not resistant in bearing the costs of providing these additional units of local public goods.

Third, I show that the positive effects on government's aggregate expenditures and revenues can be replicated for most of the budget items separately. An interesting exception emerges though. The data tells that expenditures on personnel and on property investment are negatively affected by direct democracy. One argument could be that under direct democracy voters have increased powers to limit the amount of government spending going to targeted minorities (e.g. public employees and future property owners) to the benefit of the wider electorate. Regarding public employees, for example, the initiative process enables individuals and groups outside the government to check the behavior of elected officials, who often tend to pad the public payroll with patronage workers (Matsusaka, 2009). Beyond its interest, I argue that this exception may also serve as another step in understanding the possibly reversing effect of the fiscal-taboo. The argument is that initiatives aimed at constraining public sector employment function 
through the same (above described) general mechanism of voters vetoing government's (employment) decisions. Unlike direct initiatives on the budget, however, these are in principle not excluded from the allowed topics (even though these might have non-zero implications for the budget).

To conclude, this paper should be viewed as a first step in understanding the fiscal effects of German direct democracy reforms and an important complement to the Swiss and US evidence. It is important to keep in mind that these elements of direct democracy are a relatively recent institutional innovation for the German fiscal system, and for its voters and politicians alike. Furthermore, these institutions are still evolving and the legislations are being reformed (e.g. abolition of the fiscal-taboo in Bremen (2009), liberalization of legislative and procedural barriers in Thüringen (2009) and in SchleswigHolstein (2013), etc). Therefore, there is certainly a need for more research in the area. Future work should, among other things, assess the ongoing reforms, attempt to directly test for some of the interpretations of the results of this paper, and extend the discussion beyond purely fiscal phenomena to cover other relevant economic effects of direct democracy. 
Figure 1: Frequency and topics of local initiatives across German Länder

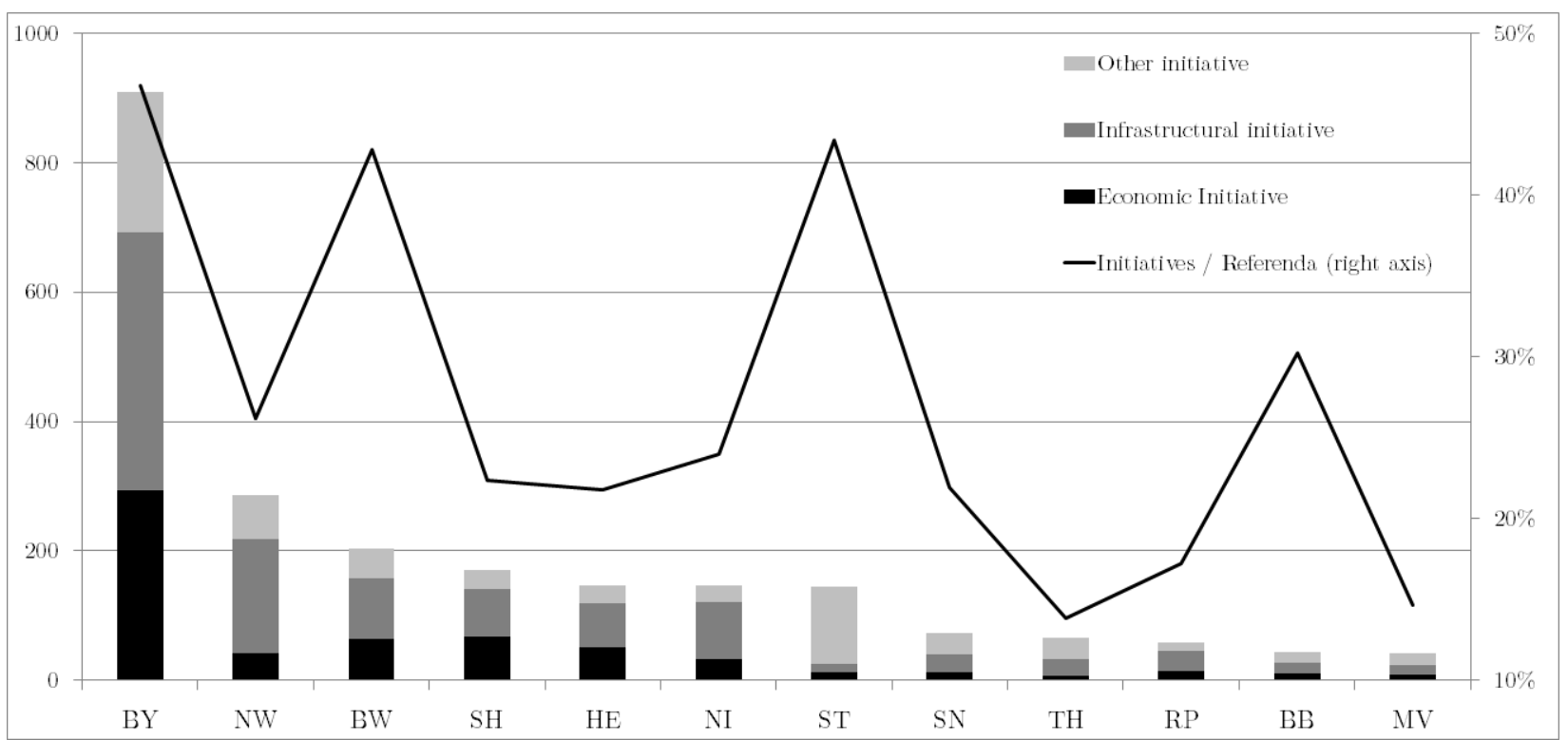

Notes: Total number of local initiatives across German Länder per topic, and their success rate in 2002-2009.

Figure 2: Costs of local initiatives and their topics

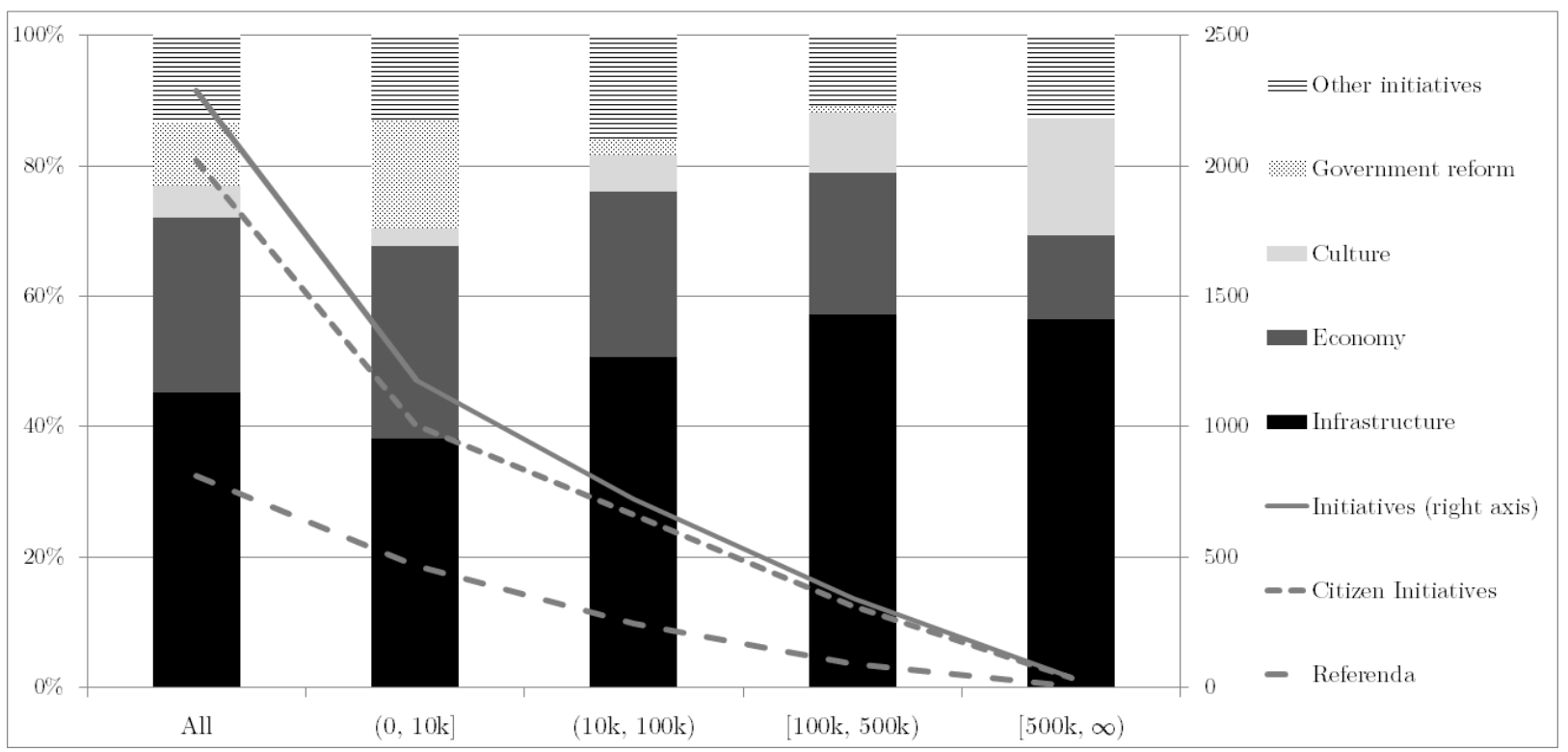

Notes: Relative amount of local initiatives and their topics across proposed cost categories (in thousand Euros) in German Länder from 2002 to 2009. 


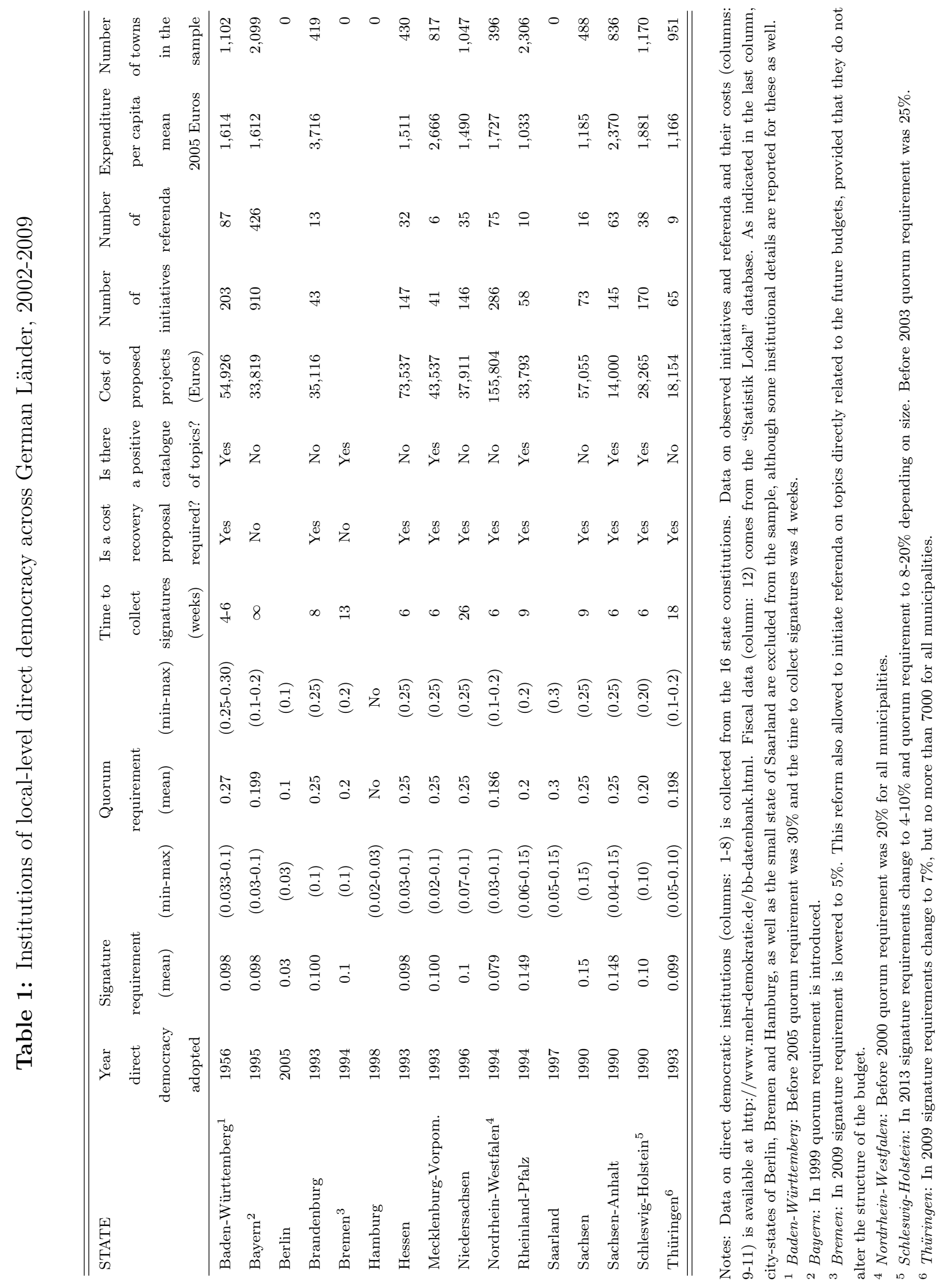




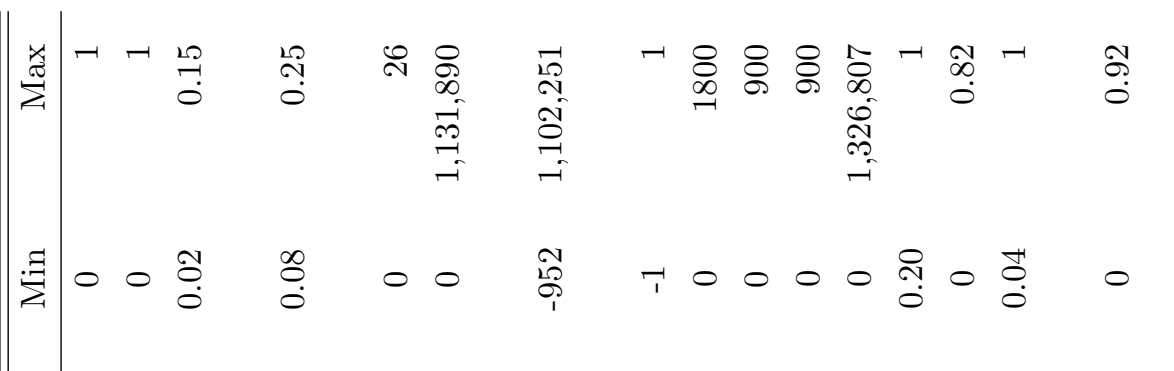

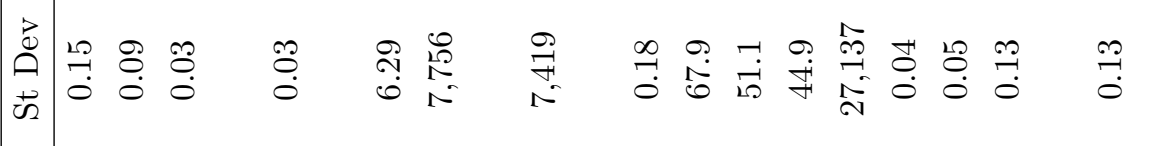

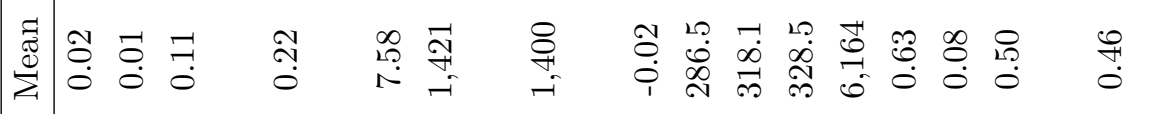

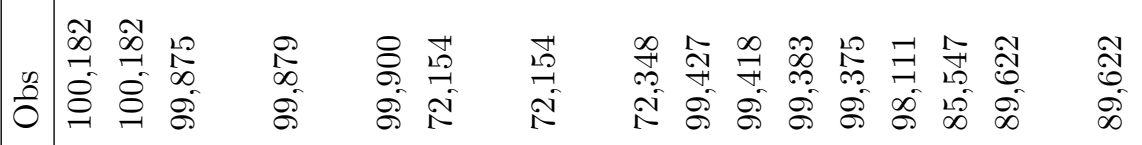

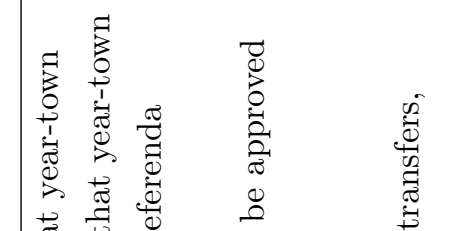

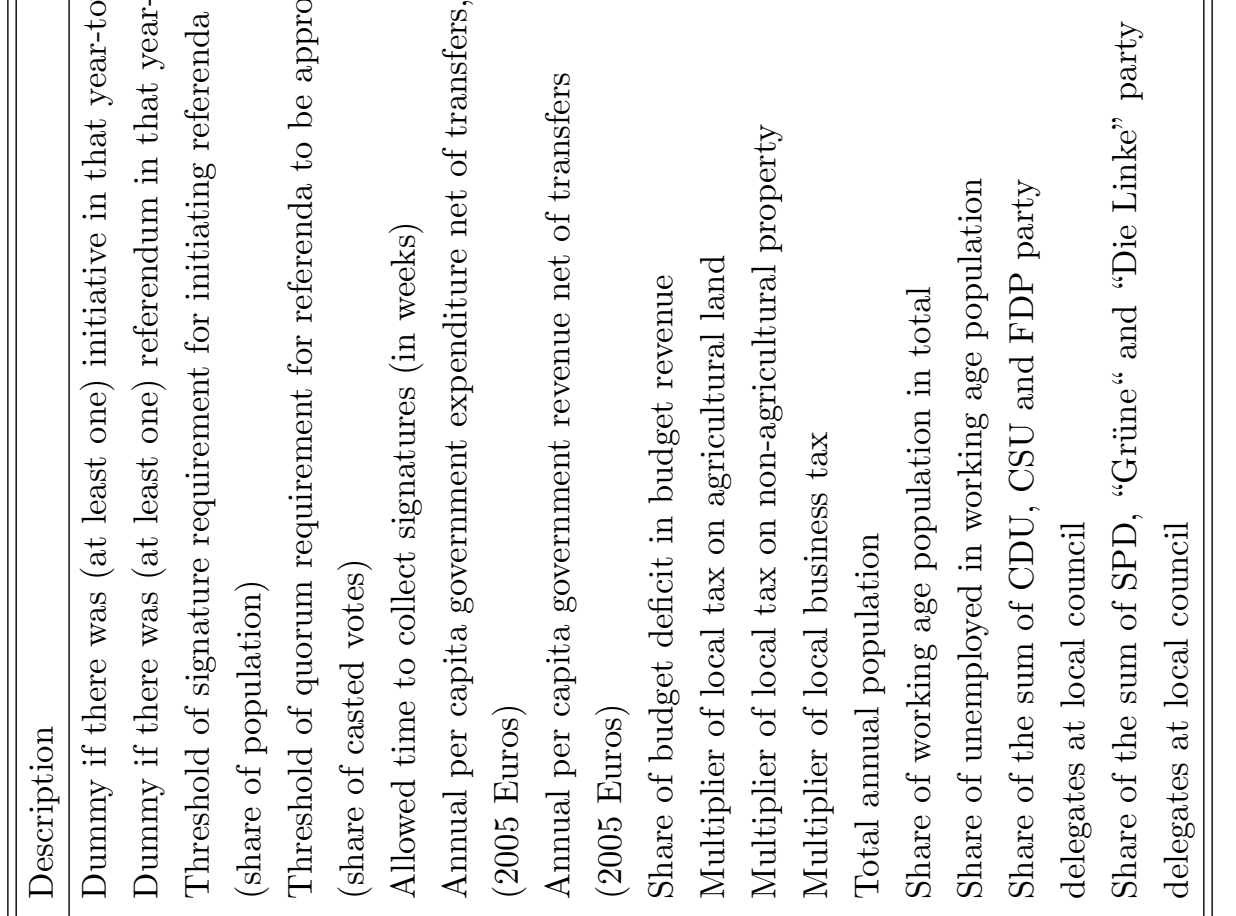

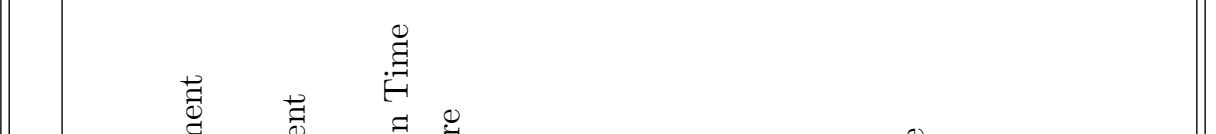

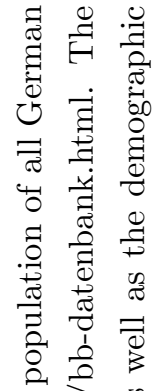

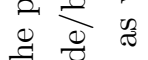
离赵离
要

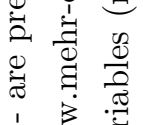
द

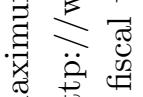
苨言
च

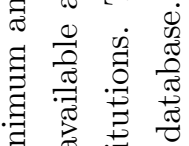

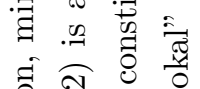

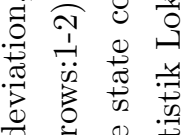
过
离.
谓苛
胥
की

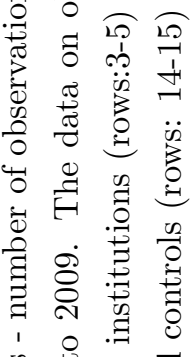

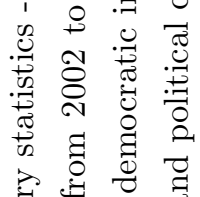

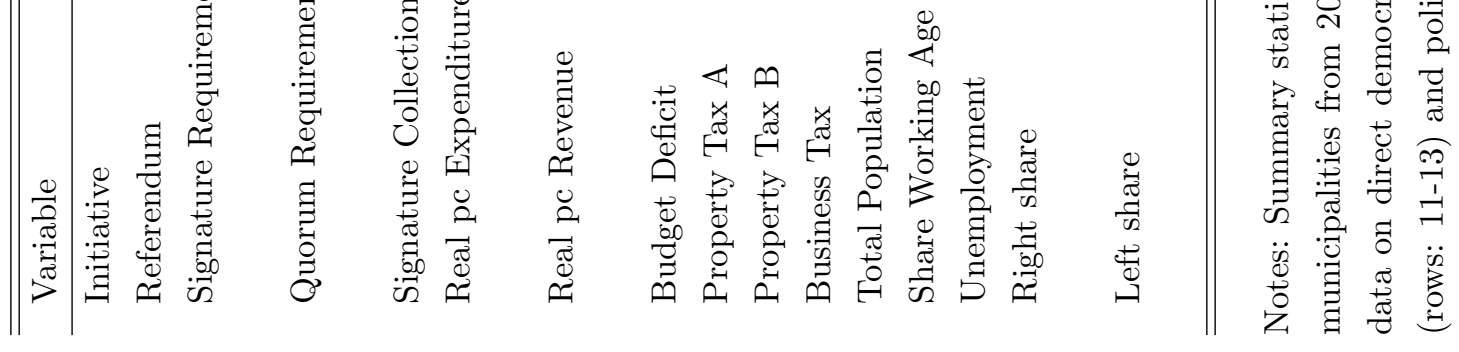

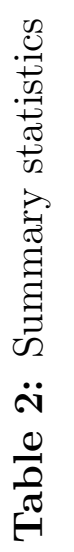




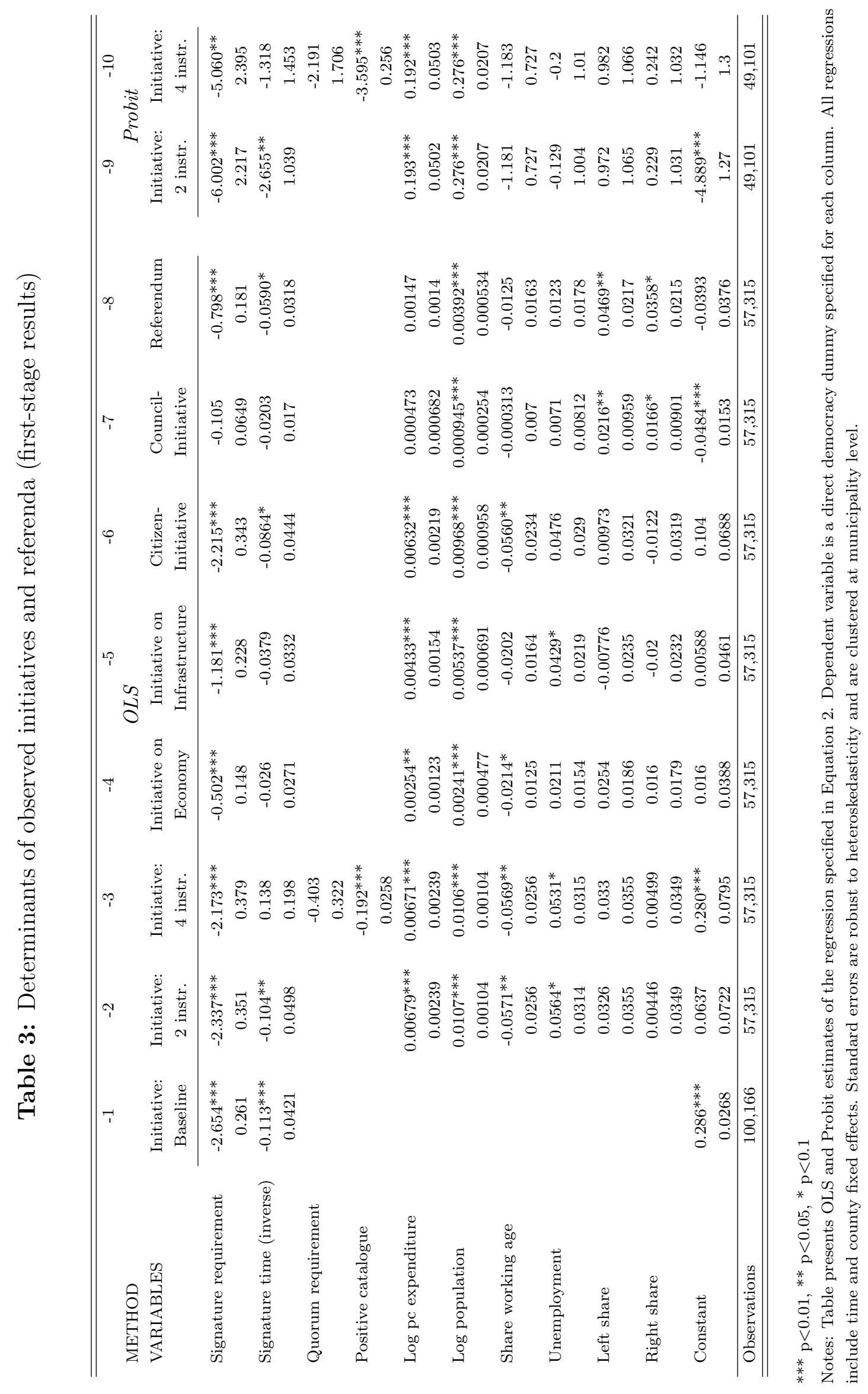




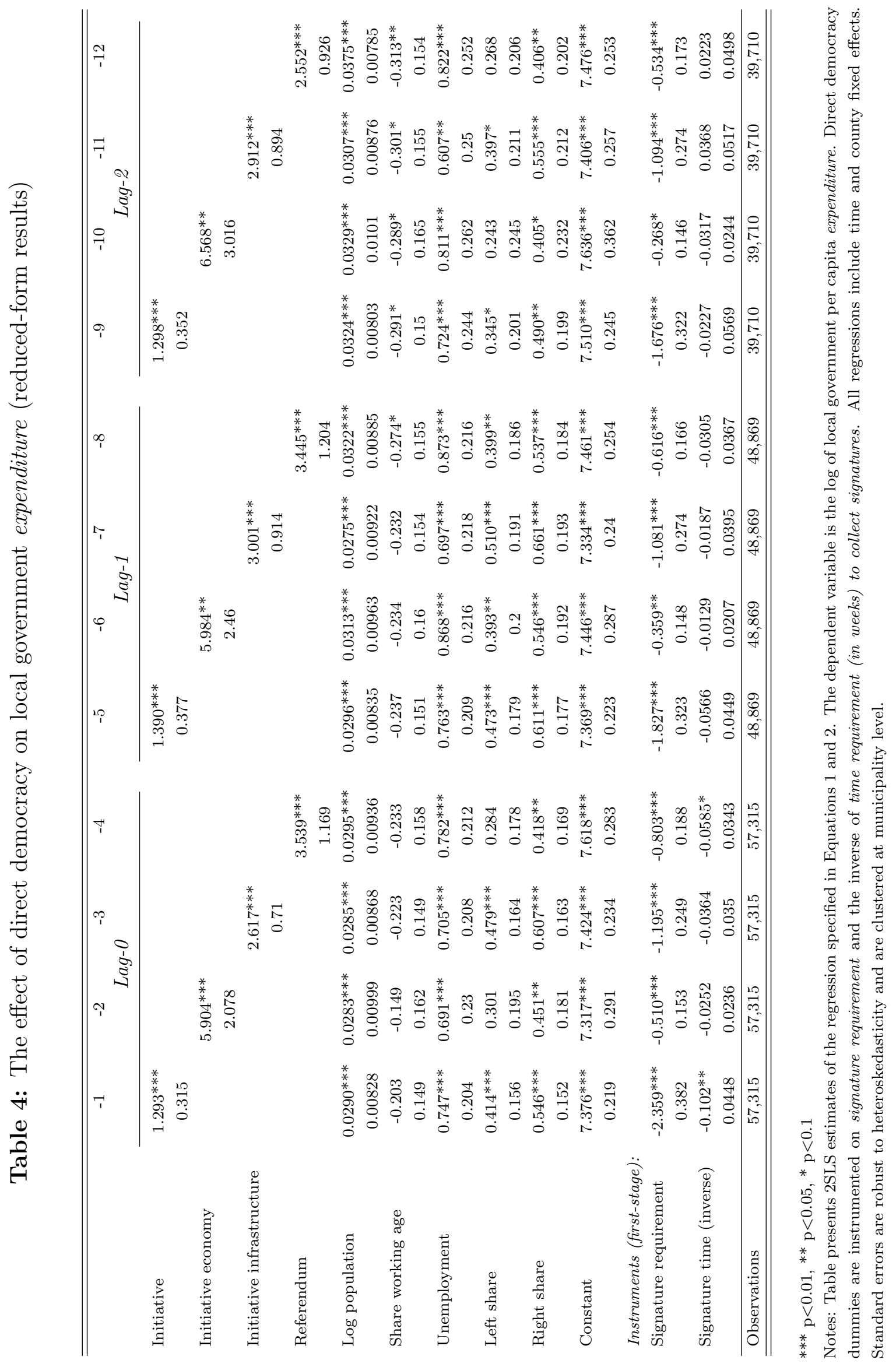




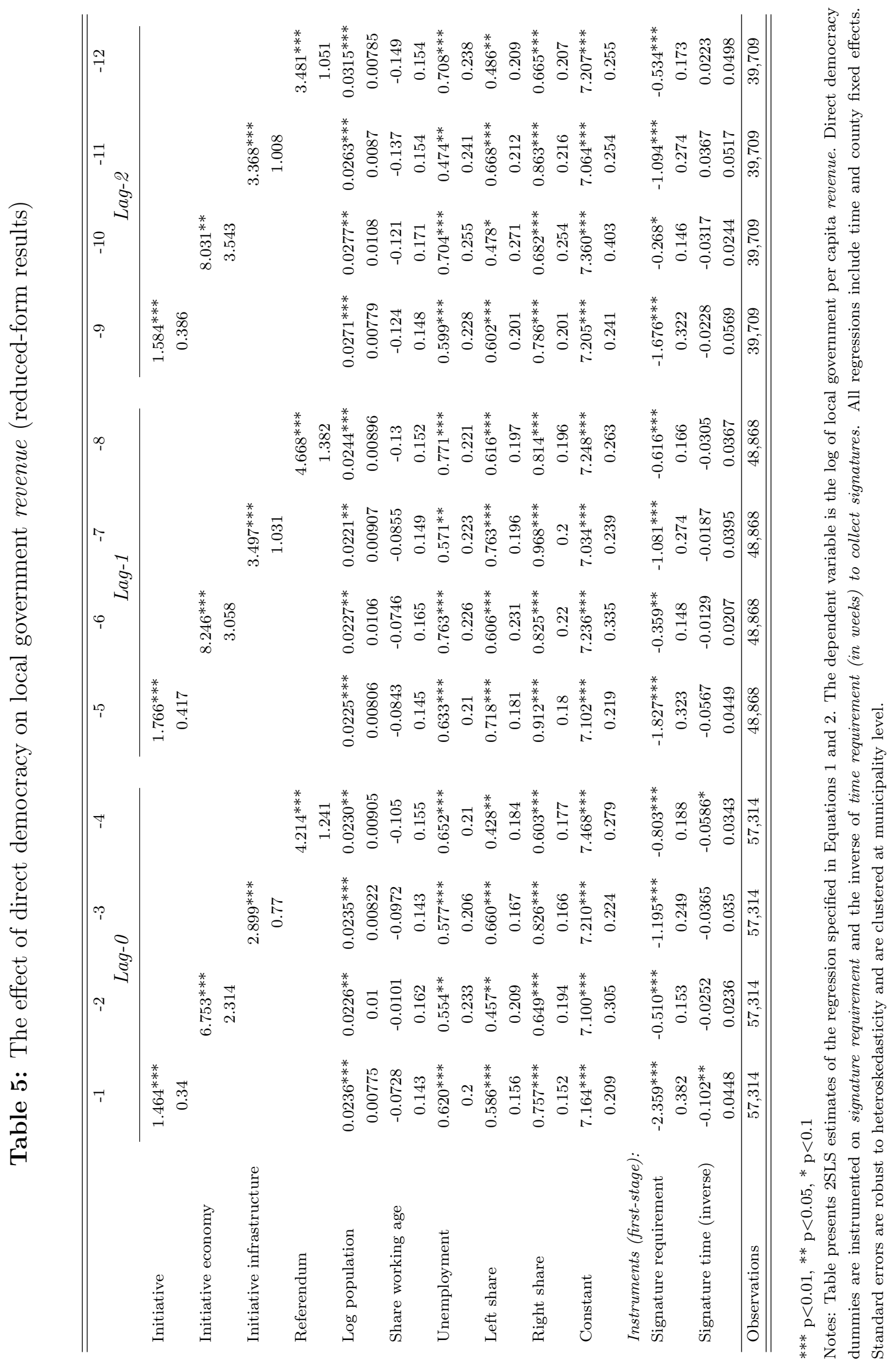




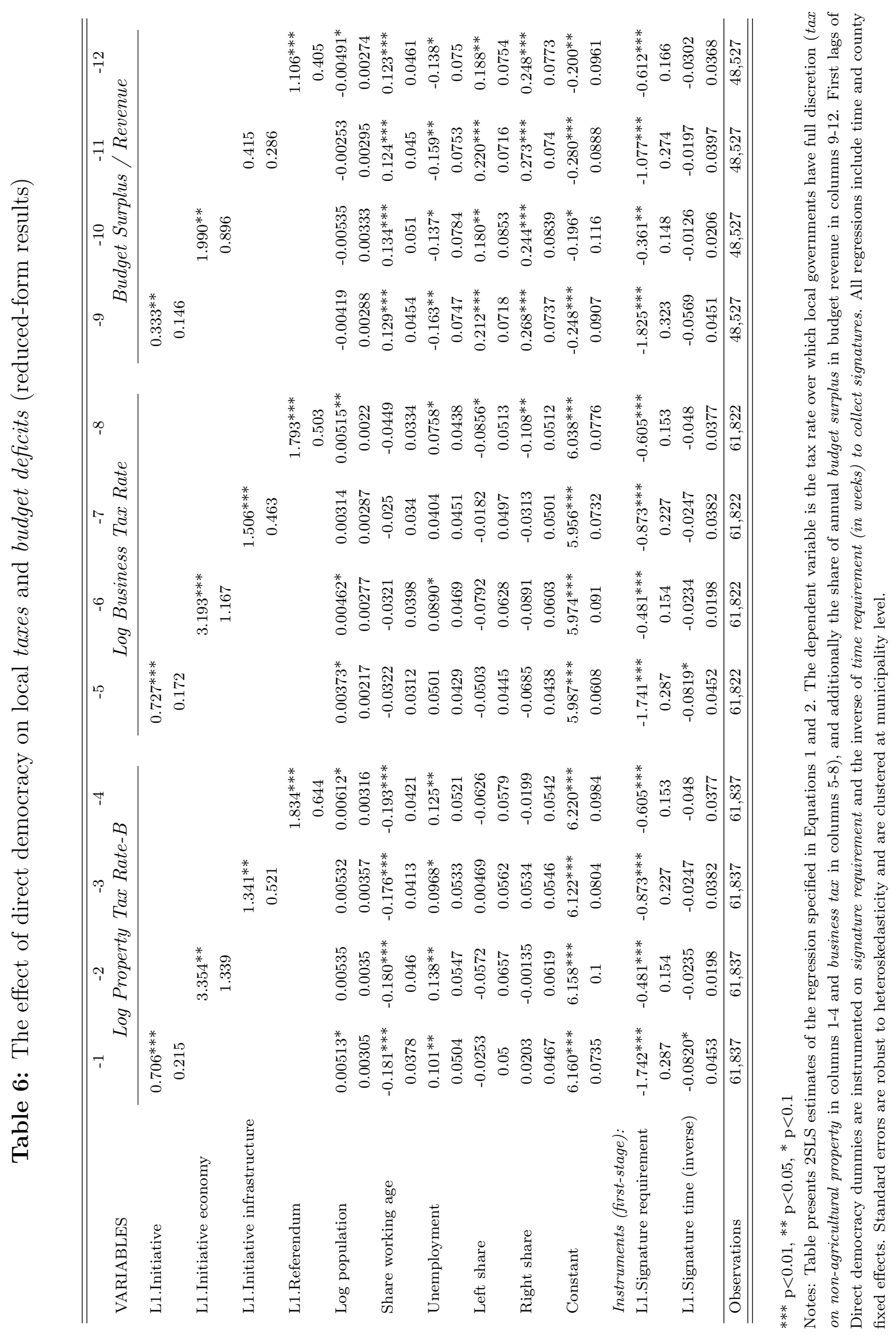


Table 7: The structure of budget expenditure and revenue for an average town

\begin{tabular}{ccc}
\hline \hline Expenditure or Revenue Category & Euro, thousand & Share \\
\hline Total Expenditure & 15,600 & 1.00 \\
Administrative, of which & 12,200 & 0.78 \\
Operating & 2,532 & 0.16 \\
Personnel & 3,341 & 0.21 \\
Capital, of which & 3,400 & 0.22 \\
Property Investment & 1,772 & 0.11 \\
Total Revenue & 14,700 & 1.00 \\
Administrative, of which & 12,200 & 0.83 \\
Own taxes & 3,272 & 0.22 \\
Capital & 2,536 & 0.17 \\
\hline \hline
\end{tabular}

Source: Own calculations based on data from "Statistik Lokal" database.

Sample: All German municipalities, 2002-2009 (unweighted averages). 


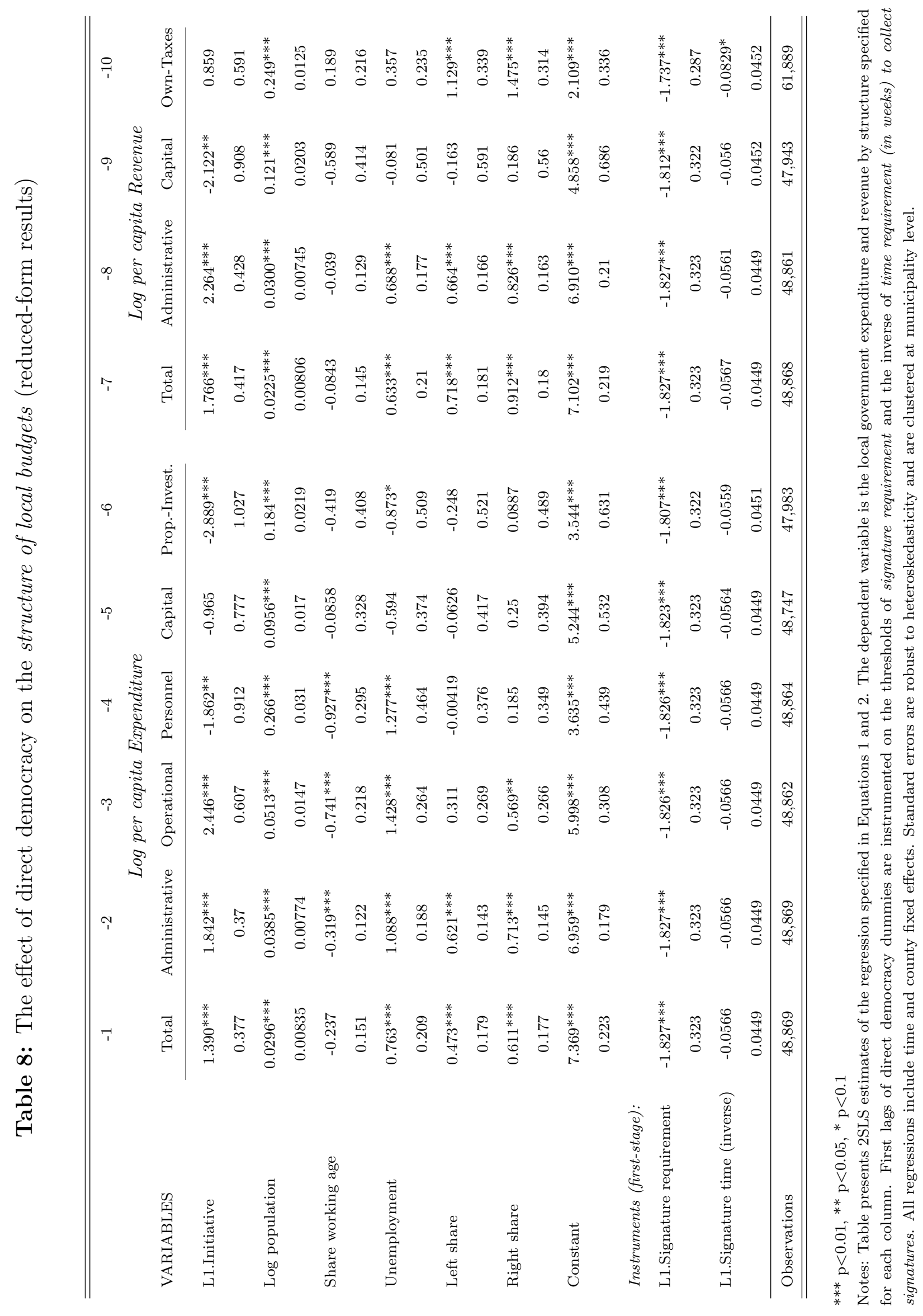




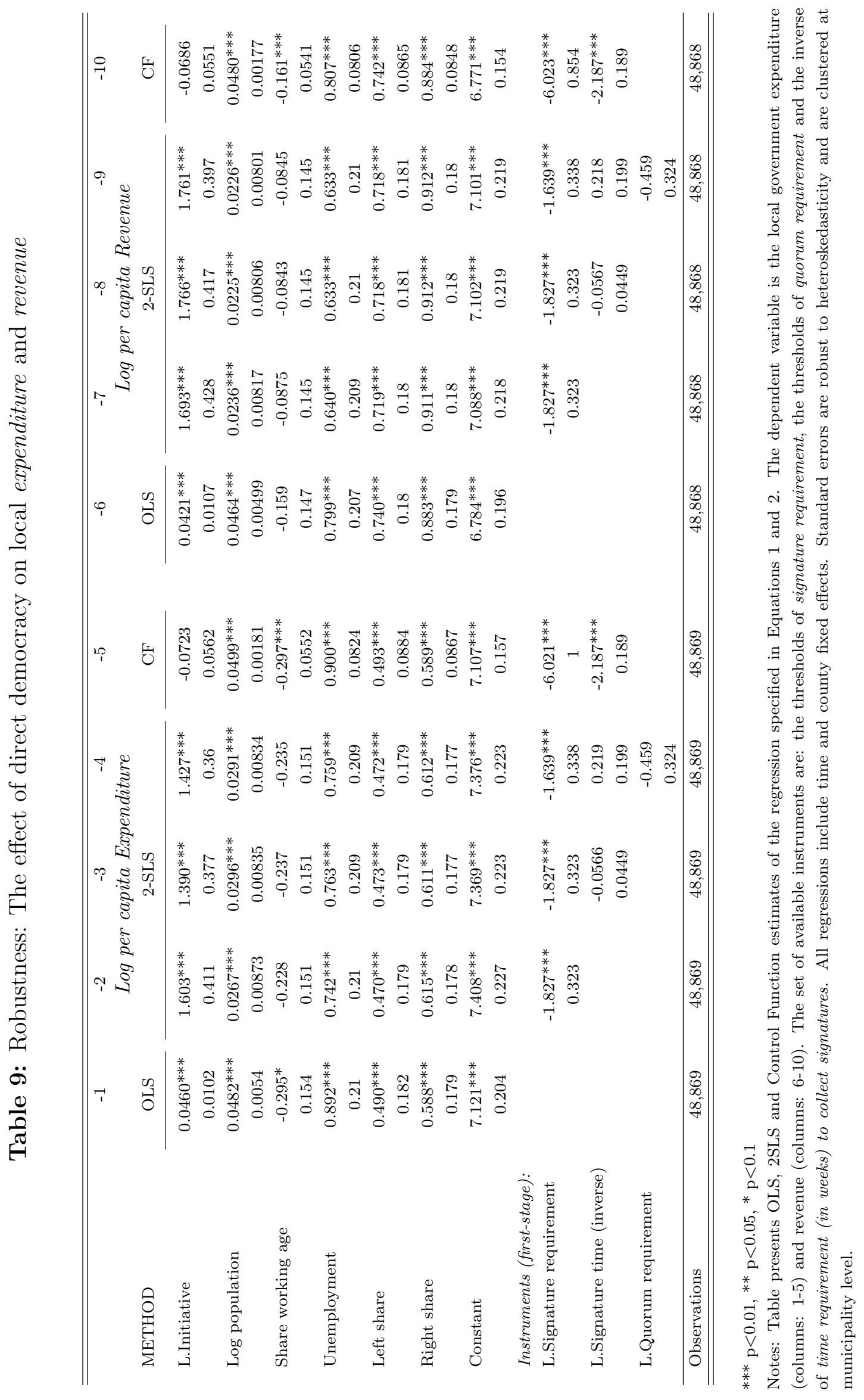




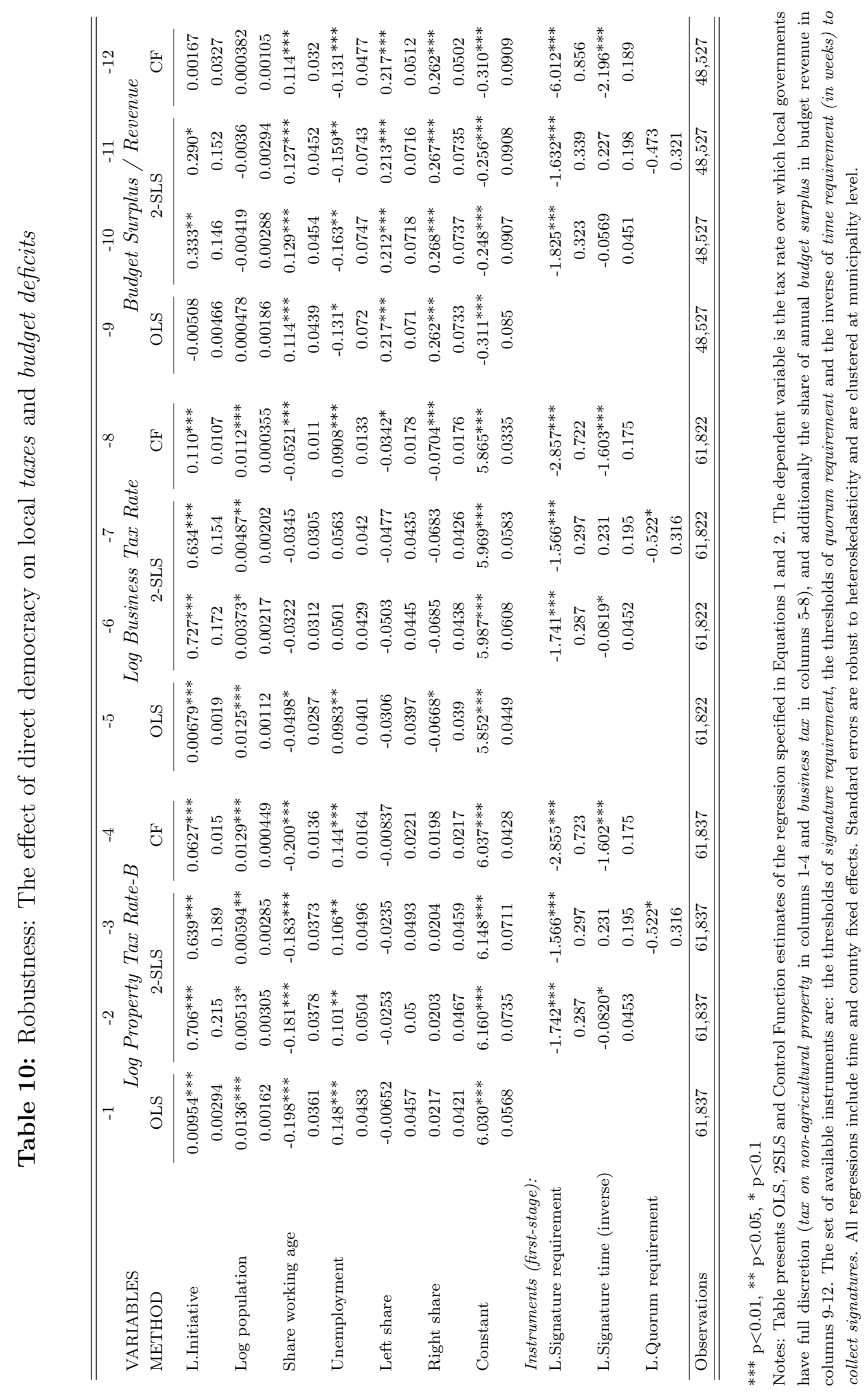




\section{References}

Angrist, J. D. (1990). Lifetime earnings and the vietnam era draft lottery: Evidence from social security administrative records. The American Economic Review 80(3), $313-336$.

Angrist, J. D. (2001). Estimation of limited dependent variable models with dummy endogenous regressors. Journal of Business and Economic Statistics 19(1), 2-16.

Angrist, J. D. and A. B. Krueger (2001). Instrumental variables and the search for identification: From supply and demand to natural experiments. Journal of Economic Perspectives 15(4), 69-85.

Angrist, J. D. and J.-S. Pischke (2008). Mostly harmless econometrics: An empiricist's companion. Princeton, NJ: Princeton University Press.

Asatryan, Z., T. Baskaran, T. Grigoriadis, and F. Heinemann (2013). Direct democracy and local public finances under cooperative federalism. Discussion Paper 13-038, ZEW.

Asatryan, Z., T. Baskaran, and F. Heinemann (2014). The effect of direct democracy on the level and structure of local taxes. Discussion Paper 14-003, ZEW.

Bails, D. and M. A. Tieslau (2000). The impact of fiscal constitutions on state and local expenditures. Cato Journal 20(2), 255-277.

Besley, T. and A. Case (2003). Political institutions and policy outcomes: Evidence from the United States. Journal of Economic Literature 41(1), 7-73.

Blomberg, S. B., G. D. Hess, and A. Weerapana (2004). The impact of voter initiatives on economic activity. European Journal of Political Economy 20(1), 207-226.

Blume, L., T. Döring, and S. Voigt (2011). Fiscal effects of reforming local constitutions: Recent German experiences. Urban Studies 48(10), 2123-2140. 
Blume, L., J. Müller, and S. Voigt (2009). The economic effects of direct democracy - a first global assessment. Public Choice 140(3-4), 431-461.

Blume, L. and S. Voigt (2012). Institutional details matter - more economic effects of direct democracy. Economics of Governance 13(4), 287-310.

Brennan, G. and J. Buchanan (1980). The power to tax: Analytical foundations of a fiscal constitution. Cambridge University Press.

Camobreco, J. F. (1998). Preferences, fiscal policies, and the initiative process. Journal of Politics 60, 819-829.

Eder, C., A. Vatter, and M. Freitag (2009). Institutional design and the use of direct democracy: Evidence from the German Länder. West European Politics 32(3), 611633.

Farnham, P. G. (1990). The impact of citizen influence on local government expenditures. Public Choice 64(3), 201-212.

Feld, L. P. and G. Kirchgässner (1999). Public debt and budgetary procedures: Top down or bottom up? Some evidence from Swiss municipalities. In J. M. Poterba (Ed.), Fiscal Institutions and Fiscal Performance, pp. 151-180. Chicago: University of Chicago Press.

Feld, L. P. and G. Kirchgässner (2001). Does direct democracy reduce public debt? Evidence from Swiss municipalities. Public Choice 109(3-4), 347-370.

Feld, L. P. and J. G. Matsusaka (2003). Budget referendums and government spending: Evidence from the Swiss Cantons. Journal of Public Economics 87(12), 2703-2724.

Freitag, M. and A. Vatter (2006). Initiatives, referendums, and the tax state. Journal of European Public Policy 13(1), 89-112.

Frey, B. S., M. Kucher, and A. Stutzer (2001). Outcome, process and power in direct democracy - new econometric results. Public Choice 107(3-4), 271-293. 
Funk, P. and C. Gathmann (2011). Does direct democracy reduce the size of government? New evidence from historical data, 1890-2000. Economic Journal 121(557), 1252-1280.

Hinnerich, B. T. and P. Pettersson-Lidbom (2012). Democracy redistribution and political participation: Evidence from Sweden 1919-1938. Working paper, Stockholm University.

Imbens, G. and W. V. D. Klaauw (1995). Evaluating the cost of conscription in the Netherlands. Journal of Business and Economic Statistics 13(2), 207-215.

Imbens, G. and J. Wooldridge (2007). What's new in econometrics. Lecture notes, NBER.

Kiewiet, D. and K. Szakaly (1996). Constitutional limitations on borrowing: An analysis of state bonded indebtedness. Journal of Law, Economics and Organization 12(1), $62-97$.

Kirchgässner, G. (2000). The effects of fiscal institutions on public finance: A survey of the empirical evidence. In S. L. Winer and H. Shibata (Eds.), Political Economy and Public Finance: The Role of Political Economy in the Theory and Practice of Public Economics, pp. 145-177. Cheltenham: Edward Elgar.

Marschall, M. J. and A. Ruhil (2005). Fiscal effects of the voter initiative reconsidered: Addressing endogeneity. State Politics and Policy Quarterly 5(4), 327-255.

Matsusaka, J. G. (1995). Fiscal effects of the voter initiative: Evidence from the last 30 years. Journal of Political Economy 103(3), 587-623.

Matsusaka, J. G. (2000). Fiscal effect of the voter initiatives in the first half of the twentieth century. Journal of Law and Economics 43, 619-650.

Matsusaka, J. G. (2009). Direct democracy and public employees. American Economic Review $99(5), 2227-2246$.

Peltzman, S. (1992). Voters as fiscal conservatives. Quarterly Journal of Economics $107(2), 327-361$. 
Pommerehne, W. (1978). Institutional approaches to public expenditures: Empirical evidence from Swiss municipalities. Journal of Public Economics 9(2), 255-280.

Primo, D. M. (2010). The effect of initiatives on local government spending. Journal of Theoretical Politcs 22(1), 6-25.

Romer, T. and H. Rosenthal (1979). Bureaucrats versus voters: On the political economy of resource allocation by direct democracy. Quarterly Journal of Economics 93(4), $563-587$

Salvino, R., M. T. Tasto, and G. K. Turnbull (2012). A direct test of direct democracy: New England town meetings. Applied Economics 44(18), 2393-2402.

Schiller, T. (2011). Local direct democracy in Germany - varieties in a federal state. In T. Schiller (Ed.), Local direct democracy in Europe, pp. 54-71. Wiesbaden: Springer.

Setala, M. and T. Schiller (2012). Citizens' initiatives in Europe: Procedures and consequences of agenda-setting by citizens. New York: Palgrave MacMillan.

Verhulst, J. and A. Nijeboer (2008). Direct democracy: Facts and arguments about the introduction of initiative and referendum. Brussels: Democracy International.

Wollmann, H. (2000). Local government modernization in Germany: Between incrementalism and reform waves. Public Administration 78(4), 915-936.

Zax, J. S. (1989). Initiatives and government expenditures. Public Choice 63(3), 267-277. 